\title{
Study on Radical Telomerization of Esters of Methacrylic Acid by Using Bromotrichloromethane and Characteristics of the Resulting Telomers III. ${ }^{\dagger}$ Aryl Methacrylates
}

\author{
Takao KIMURA, Itaru NAKANISHI, ${ }^{*}$ and Motome HAMASHIMA \\ Department of Environmental Chemistry, Faculty of Engineering, \\ Utsunomiya University, Ishii-cho, Utsunomiya 321, Japan
}

(Received March 11, 1986)

\begin{abstract}
Radical telomerization of phenyl (PhMA), 1-naphthyl (1-NMA), and 2-naphthyl (2-NMA) methacrylates was carried out using bromotrichloromethane (BTCM) as a telogen at 50, 70 , and $90^{\circ} \mathrm{C}$. The telomerization of these aryl methacrylates showed similar product distributions and tacticity as those of methyl methacrylate (MMA), but without formation of lactones. The order of the apparent rate of telomerization was as follows: MMA $\cong \mathrm{PhMA}>1-\mathrm{NMA} \gg 2-\mathrm{NMA}$. The $n$ [Monomer] :[BTCM] adducts, that is, the $n$-mers $(n=1-3)$, were separated by silica gel column chromatography. The aryl methacrylate and MMA telomers differed remarkably from each other in reactivity. The elimination reaction of the aromatic telomers with triethylamine was labile and complicated in comparison with that of the MMA telomers, and the dimers were subject to scission of the principal chain besides the normal elimination reaction. The catalytic lactonization of the aromatic dimers with silica gel was slower than that of the MMA dimers. The pyrolysis of the aromatic dimers gave unsaturated compounds in preference to lactones, which were exclusively obtained in the pyrolysis of the MMA dimers. Furthermore, the pyrolysis of the NMA dimers resulted in the diastereoisomerization through depolymerization.
\end{abstract}

KEY WORDS Radical Telomerization / Phenyl Methacrylate / 1-Naphthyl

Methacrylate / 2-Naphthyl Methacrylate / Bromotrichloromethane /

Telomers / Elimination Reaction / Lactonization / Pyrolysis

Diastereoisomerization /

Bromotrichloromethane (BTCM) is known as a strong telogen for the radical telomerization of vinyl monomers on the basis of kinetic studies. ${ }^{1-5}$ However, there have been reported few studies on the separation and the characterization of telomers synthesized by using BTCM as a telogen. ${ }^{6}$

Since the corresponding telomeric molecules have labile substituent groups at both ends, they can be utilized as "reactive oligomers" by way of chemical modification of their functional groups. Furthermore, studies on the stereochemistry and the reactivity of the telomers provide valuable data as model compounds for oligomers, and detailed analyses of the telomers are available for molecular design of new oligomers.

Our previous paper reported that methyl methacrylate (MMA) telomers up to trimers synthesized in the presence of BTCM were separated and their structures were investigated by means of ${ }^{1} \mathrm{H}$ NMR spectroscopy and chemical reactions. ${ }^{7}$ In the preceding paper, ${ }^{8}$ we described the radical telomerization of a series of primary alkyl $\left(\mathrm{C}_{1}-\mathrm{C}_{4}\right)$ methacrylates in the presence of $\mathrm{BTCM}$ and the characteristics of the resulting telomers.

As a part of the study program, this work

+ Part I and II of this series are ref 7 and 8.

* Present address: Niigata Branch Office, Hoechst Japan Ltd., 1-31, Yoneyama 4-chome, Niigata 950, Japan. 
deals with the radical telomerization of aryl methacrylates, that is, phenyl (PhMA), 1naphthyl (1-NMA), and 2-naphthyl (2-NMA) methacrylates using BTCM. The telomerization behavior and reactivity of the resulting telomers are compared for a series of aryl methacrylates and MMA, and the effects of the aryl groups are discussed.

\section{EXPERIMENTAL}

\section{Measurements}

The instruments and methods used in this experiment have been described elsewhere. ${ }^{8}$

\section{Materials}

PhMA, 1-NMA, and 2-NMA were prepared by the reactions of methacryloyl chloride with the corresponding phenols in $5 \%$ aqueous sodium hydroxide according to the procedure of Patai. ${ }^{9}$ These monomers were purified by distillation under reduced pressure or recrystallization from methanol. PhMA: bp $95-97^{\circ} \mathrm{C}[10 \mathrm{mmHg}(1.33 \mathrm{kPa})] ;$ lit. $^{10} 64$ $66^{\circ} \mathrm{C} \quad[2 \mathrm{mmHg} \quad(0.27 \mathrm{kPa})]$ 1-NMA: $\mathrm{mp}$ $38.5-39.5^{\circ} \mathrm{C}$; lit. $^{10}$ bp $137-140^{\circ} \mathrm{C}[4 \mathrm{mmHg}$ $(0.53 \mathrm{kPa})$ ]. 2-NMA: $\mathrm{mp} \quad 65.5-67^{\circ} \mathrm{C}$; lit. $^{10}$ $65-66^{\circ} \mathrm{C}$. Commercial BTCM was distilled under reduced pressure before use, and 2,2'azobisisobutyronitrile (AIBN) was recrystallized from methanol.

\section{Telomerization Procedure}

Telomerization was carried out at 50, 70 , and $90^{\circ} \mathrm{C}$ for a prescribed time, respectively, under the conditions of $[\mathrm{BTCM}]_{0} /$ $[\text { Monomer }]_{0}=8$ and $[\mathrm{AIBN}]_{0}^{0.5} /[\text { Monomer }]_{0}=$ 0.5 . The reaction mixture was treated in a manner similar to the case of the previous paper. $^{7}$

\section{Separation and Identification of Telomers}

The $n$-mers $(n=1-3)$ were separated by silica gel column chromatography (packing material, Wakogel C-300; eluent, 1:1-benzene:carbon tetrachloride for PhMA telo- mers; 1:2-benzene: carbon tetrachloride for 1- and 2-NMA telomers). Separation was achieved rapidly by pressing with nitrogen gas to avoid any side reactions such as lactonization in the column. The eluting order of the telomers was as follows: 1-mer (1)>syndiotactic (st)-dimer $\quad(\mathbf{2 a})>($ monomer $) \geqq i s o-$ tactic (it)-dimer (2b) $>$ st-trimer (3a). Strongly adsorbed components containing oligomers higher than trimer were desorbed by methanol.<smiles>[R]OC(=O)C(C)(Br)C(C)C</smiles>

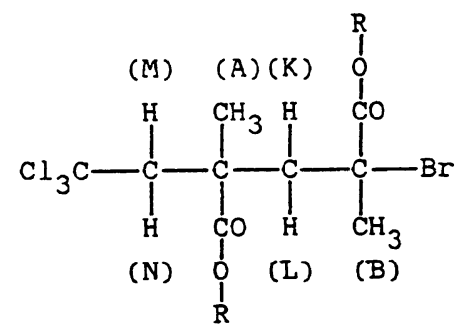

2a<smiles>[R]OC(=O)C(C)(Br)C(C)(C)C([2H])(C)C(C)(C)C</smiles><smiles>[R]OC(=O)C(C)(Br)C(C)(C(=O)O[R])C(C)(C(=O)O[R])C(C)(C(=O)O[R])C(C)(C)C</smiles> 
Identification of the series of telomers was carried out by a technique similar to that in the previous paper. ${ }^{7}$

\section{Reactions of Telomers}

Elimination Reaction by Triethylamine (TEA). A mixture of a telomer sample and TEA ( $5 \mathrm{~g}$ in $50 \mathrm{ml}$ for $1 ; 3 \mathrm{~g}$ in $60 \mathrm{ml}$ for 2a) was refluxed with stirring for a prescribed time. The reaction mixture was treated as in the previous paper. ${ }^{7}$

Catalytic Reaction by Silica Gel. To a solution of a dimeric sample $(0.3 \mathrm{~g}$ in $9 \mathrm{ml}$ dry benzene), $3 \mathrm{~g}$ of silica gel (Wakogel C-300, dried at $180-200^{\circ} \mathrm{C}$ for $3 \mathrm{~h}$ ) were added, and the suspended mixture was stirred at $30^{\circ} \mathrm{C}$ for $72 \mathrm{~h}$. The reaction mixture was treated in a manner similar that in the previous paper. ${ }^{8}$

Pyrolysis. A dimeric sample was directly heated at a given temperature for a given time. The products were separated by silica gel column chromatography with 2:1-benzene: carbon tetrachloride.

\section{RESULTS AND DISCUSSION}

\section{Telomerization of Aryl Methacrylates with BTCM}

The results of the radical telomerization of a series of aryl methacrylates along with MMA are summarized in Table I. The apparent rate of telomerization $\left(R_{\mathrm{p}}^{\prime}\right)$ of these aryl methacrylates was greatly dependent on the kinds of aryl substituents in the ester group, the order of $R_{\mathrm{p}}^{\prime}$ being $\mathrm{MMA} \cong \mathrm{PhMA}>1-\mathrm{NMA} \gg 2$ NMA. In particular, the $R_{\mathrm{p}}^{\prime}$ of 2-NMA was unexpectedly so low that the telomerization of 2-NMA could not be carried out below $70^{\circ} \mathrm{C}$. However, the telomerization of these aryl methacrylates showed similar product distribution (MWD) and tacticity as that of MMA, but without formation of lactones.

\section{Identification of Telomers}

The characterization of the homologous telomers is listed in Table II. The ion peaks based on an identical fragmentation pattern were generally detected in the mass spectra of the homologues. That is, the $\alpha$-cleavage of

Table I. Radical telomerization of aryl methacrylates

\begin{tabular}{|c|c|c|c|c|c|c|c|c|}
\hline \multirow{2}{*}{ Monomer } & \multirow{2}{*}{$\frac{\text { Temp }}{{ }^{\circ} \mathrm{C}}$} & \multirow{2}{*}{$\frac{\text { Time }}{\mathrm{h}}$} & \multirow{2}{*}{$\frac{R_{\mathrm{p}}^{\prime} \times 10^{6}}{\mathrm{mol1}^{-1} \mathrm{~s}^{-1}}$} & \multicolumn{3}{|c|}{ MWD/wt $\%$} & \multicolumn{2}{|c|}{ Tacticity of dimer $/ \%$} \\
\hline & & & & $n=1$ & $n=2^{\mathrm{a}}$ & $n \geqq 3$ & $\mathbf{2 a}$ & $\mathbf{2 b}$ \\
\hline \multirow{3}{*}{ MMA } & 50 & 24 & 8 & 6 & $13[0]$ & 81 & 85 & 15 \\
\hline & 70 & 8 & 79 & 22 & $26[2]$ & 52 & 78 & 22 \\
\hline & 90 & 4 & 147 & 29 & $30[3]$ & 41 & 75 & 25 \\
\hline \multirow{3}{*}{ PhMA } & 50 & 24 & 20 & 4 & $7[0]$ & 89 & 91 & 9 \\
\hline & 70 & 8 & 59 & 6 & $10[0]$ & 84 & 87 & 13 \\
\hline & 90 & 4 & 127 & 20 & $21[0]$ & 59 & 80 & 20 \\
\hline \multirow{3}{*}{ 1-NMA } & 50 & 72 & 5 & 6 & $7[0]$ & 87 & 87 & 13 \\
\hline & 70 & 24 & 20 & 18 & $18[0]$ & 64 & 78 & 22 \\
\hline & 90 & 12 & 46 & 25 & $18[0]$ & 57 & 73 & 27 \\
\hline \multirow{3}{*}{ 2-NMA } & $50^{b}$ & - & - & - & - & - & - & - \\
\hline & $70^{\mathrm{b}}$ & - & - & - & - & - & - & - \\
\hline & 90 & 72 & 6 & 18 & $15[0]$ & 67 & 72 & 28 \\
\hline
\end{tabular}

a [ ], content of dimeric lactones.

b Not carried out. 
ester groups, the cleavage between halogen and carbon atoms, and the cleavage of the principal chain into a monomeric cation occurred preferentially.
The ${ }^{1} \mathrm{H}$ NMR parameters of the homologous telomers along with MMA ones are summarized in Table III. All methyl- and methylene-proton signals of these aromatic

Table II. Characterization of telomers

\begin{tabular}{|c|c|c|c|c|}
\hline \multirow{2}{*}{ Telomer } & \multirow{2}{*}{$\mathbf{R}^{\mathrm{a}}$} & $\mathrm{mp}$ & $v(\mathrm{C}=\mathrm{O})$ & \multirow{2}{*}{$m / z\left(\mathrm{QM}^{+}\right)$} \\
\hline & & ${ }^{\circ} \mathrm{C}$ & $\mathrm{cm}^{-1}$ & \\
\hline \multirow{3}{*}{1} & $\mathrm{Ph}$ & $51.5-53$ & 1760 & 359 \\
\hline & $1-\mathrm{Np}$ & $92-93.5$ & 1760 & 409 \\
\hline & $2-\mathrm{Np}$ & $86-87.5$ & 1760 & 409 \\
\hline \multirow{3}{*}{$\mathbf{2 a}$} & $\mathrm{Ph}$ & $87-89$ & 1755 & 521 \\
\hline & $1-\mathrm{Np}$ & $158-159.5(\mathrm{dec})$ & 1750 & 621 \\
\hline & $2-\mathrm{Np}$ & $145.5-147$ (dec) & 1755 & 621 \\
\hline \multirow{3}{*}{$\mathbf{2 b}$} & $\mathrm{Ph}$ & $86-87$ & 1760 & 521 \\
\hline & $1-\mathrm{Np}$ & $106-109 \quad(\mathrm{dec})$ & 1765 & 621 \\
\hline & $2-\mathrm{Np}$ & $78-81 \quad(\mathrm{dec})$ & 1760,1750 & 621 \\
\hline \multirow{3}{*}{ 3a } & $\mathrm{Ph}$ & $142.5-144 \quad(\mathrm{dec})$ & 1755,1750 & $-^{b}$ \\
\hline & $1-\mathrm{Np}$ & $129-133 \quad(\mathrm{dec})$ & 1760,1755 & $-^{\mathrm{b}}$ \\
\hline & $2-\mathrm{Np}$ & $189-192 \quad(\mathrm{dec})$ & 1755 & - $^{\mathrm{b}}$ \\
\hline
\end{tabular}

a Ph, phenyl; 1-Np, 1-naphthyl; 2-Np, 2-naphthyl.

b Immeasurement.<smiles>[R]OC(=O)C(C)CC</smiles>

5<smiles></smiles>

6<smiles>[R2]OC(=O)C(C)(C(C)=C(C)C([R20])=O)C(C)(C)CC(C)(C)C</smiles>

$n=1: 4$

$n=2: 7 \mathrm{~b}$

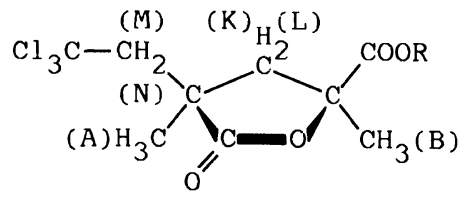

$\mathbf{8 a}$<smiles>[R]OC(=O)CC(C)(CC)C([R])[R]</smiles>

$7 a$<smiles>[R]OC(=O)C(C)(C)OC(=O)C(C)(CCC)C(C)(C)CC</smiles>

8b 
Telomerization of Aryl Methacrylates by BTCM

Table III. ${ }^{1} \mathrm{H}$ NMR parameters of telomers

\begin{tabular}{|c|c|c|c|c|c|c|}
\hline \multirow{2}{*}{ Telomer } & \multirow{2}{*}{ Proton } & \multirow{2}{*}{ Symbol } & \multicolumn{4}{|c|}{ Chemical shift $\delta /$ ppm } \\
\hline & & & $\mathrm{MMA}^{\mathrm{a}}$ & $\mathrm{PhMA}^{\mathrm{a}}$ & $1-\mathrm{NMA}^{\mathrm{b}}$ & $2-\mathrm{NMA}^{\mathrm{b}}$ \\
\hline 1 & $\begin{array}{l}-\mathrm{CH}_{3} \\
-\mathrm{CH}_{2}-\end{array}$ & $\begin{array}{r}A \\
M, N\end{array}$ & $\begin{array}{c}2.19 \\
4.213 .50 \\
(15.6)^{d}\end{array}$ & $\begin{array}{c}2.31 \\
4.423 .63 \\
(15.6)\end{array}$ & $\begin{array}{c}2.41 \\
4.563 .72 \\
(15.6)\end{array}$ & $\begin{array}{c}2.37 \\
4.503 .71 \\
(15.6)\end{array}$ \\
\hline \multirow{4}{*}{$\mathbf{2 a}$} & $-\mathrm{CH}_{3}$ & A & 1.83 & 2.18 & 2.34 & 2.31 \\
\hline & $-\mathrm{CH}_{3}$ & B & 1.29 & 1.64 & 1.88 & 1.77 \\
\hline & $-\mathrm{CH}_{2}-$ & $\mathrm{K}, \mathrm{L}$ & $\begin{array}{c}2.902 .63 \\
(14.4)\end{array}$ & $\begin{array}{c}3.152 .82 \\
(13.2)\end{array}$ & $\begin{array}{c}3.473 .17 \\
(13.2)\end{array}$ & $\begin{array}{c}3.333 .01 \\
(14.4)\end{array}$ \\
\hline & $-\mathrm{CH}_{2}-$ & $\mathrm{M}, \mathrm{N}$ & $\begin{array}{c}3.522 .84 \\
(14.4)\end{array}$ & $\begin{array}{c}3.742 .97 \\
(15.0)\end{array}$ & $\begin{array}{c}3.963 .18 \\
(14.4)\end{array}$ & $\begin{array}{c}3.933 .11 \\
(15.0)\end{array}$ \\
\hline \multirow{4}{*}{$\mathbf{2 b}$} & $-\mathrm{CH}_{3}$ & A & 1.97 & 2.23 & 2.36 & 2.34 \\
\hline & $-\mathrm{CH}_{3}$ & B & 1.55 & 1.81 & 2.02 & 1.92 \\
\hline & $-\mathrm{CH}_{2}^{-}$ & $\mathrm{K}, \mathrm{L}$ & $\begin{array}{c}2.852 .37 \\
(15.0)\end{array}$ & $\begin{array}{c}3.182 .63 \\
(15.0)\end{array}$ & $\begin{array}{c}3.492 .96 \\
(14.4)\end{array}$ & $\begin{array}{c}3.342 .81 \\
(15.6)\end{array}$ \\
\hline & $-\mathrm{CH}_{2}-$ & $\mathbf{M}, \mathbf{N}$ & $\begin{array}{c}3.592 .87 \\
(15.0)\end{array}$ & $\begin{array}{c}3.843 .09 \\
(15.0)\end{array}$ & $\begin{array}{c}3.943 .38 \\
(15.0)\end{array}$ & $\begin{array}{c}3.963 .24 \\
(15.6)\end{array}$ \\
\hline \multirow{6}{*}{$3 a^{c}$} & $-\mathrm{CH}_{3}$ & A & 1.77 & 2.20 & 2.28 & 2.46 \\
\hline & $-\mathrm{CH}_{3}$ & B & 0.87 & 1.46 & 1.69 & 1.83 \\
\hline & $-\mathrm{CH}_{3}$ & $\mathrm{C}$ & 1.28 & 1.70 & 1.87 & 2.00 \\
\hline & $-\mathrm{CH}_{2}-$ & $\mathrm{I}, \mathrm{J}$ & $\begin{array}{c}2.792 .53 \\
(13.8)\end{array}$ & $\begin{array}{c}3.192 .86 \\
(13.8)\end{array}$ & $\begin{array}{c}3.503 .23 \\
(14.4)\end{array}$ & $\begin{array}{c}3.593 .28 \\
(15.6)\end{array}$ \\
\hline & $-\mathrm{CH}_{2}-$ & $\mathrm{K}, \mathrm{L}$ & 2.02 & 2.39 & 2.74 & 2.78 \\
\hline & $-\mathrm{CH}_{2}-$ & $\mathrm{M}, \mathbf{N}$ & $\begin{array}{c}3.412 .73 \\
(15.0)\end{array}$ & $\begin{array}{c}3.652 .95 \\
(15.0)\end{array}$ & $\begin{array}{c}3.883 .13 \\
(15.0)\end{array}$ & $\begin{array}{c}.4 .003 .44 \\
(15.6)\end{array}$ \\
\hline
\end{tabular}

${ }^{a}$ Measured in carbon tetrachloride.

b Measured in chloroform- $d_{1}$.

c $3 \mathrm{a}(\mathrm{R}=2-\mathrm{Np})$ was measured in pyridine- $d_{5}$.

d ( ), coupling const. $J$ in $\mathrm{Hz}$.

telomers resonated in lower magnetic fields relative to the corresponding proton signals of MMA ones, and the $\delta$-values of the same symbolized proton signals were roughly in the order: 1-NMA $>2-N M A>$ PhMA $\gg$ MMA. All methylene protons of the homologues except for the central methylene protons $(\mathrm{K}, \mathrm{L})$ of 3a exhibited an AB pattern (doubletdoublet) due to the magnetic unequivalence, and the magnitude of the magnetic unequivalence of these aromatic telomers was generally more than that of MMA ones. The aromatic proton signals of the ester groups, which are omitted in the table, appeared in expected resonance regions.

\section{Reactivity of Telomers}

Products (4), (5), (6), (7a), (7b), (8a), and (8b) were obtained in the three induced reactions described below. The characterization and ${ }^{1} \mathrm{H}$ NMR parameters of these products except for crude $\mathbf{5}, \mathbf{7 a}$, and $\mathbf{7 b}$ are summarized in Table IV and $\mathrm{V}$, respectively.

Elimination Reaction by TEA. Table VI and VII show the results of the reaction of 1 and $2 a$ with TEA, respectively. The elimination reaction of the aromatic telomers with TEA was found to be labile and complicated in comparison with that of the aliphatic, such as MMA telomers. The aromatic 1 gave the dimerized elimination product $\mathbf{6}$ besides the 
T. KimUra, I. NAKANiShI, and M. Hamashima

Table IV. Characterization of products derived from telomers

\begin{tabular}{|c|c|c|c|c|c|}
\hline \multirow{2}{*}{ Product } & \multirow{2}{*}{$\mathbf{R}^{\mathbf{a}}$} & $\mathrm{mp}[\mathrm{bp}]$ & $v(\mathrm{C}=\mathrm{O})$ & $v(\mathrm{C}=\mathrm{C})$ & \multirow{2}{*}{$m / z\left(\mathrm{QM}^{+}\right)$} \\
\hline & & ${ }^{\circ} \mathrm{C}$ & $\mathrm{cm}^{-1}$ & $\mathrm{~cm}^{-1}$ & \\
\hline \multirow{3}{*}{4} & $\mathrm{Ph}$ & {$[122 / 2 \mathrm{mmHg}]$} & 1745 & 1640 & 279 \\
\hline & $1-\mathrm{Np}$ & $78.5-80$ & 1740 & 1635 & 329 \\
\hline & $2-\mathrm{Np}$ & $71.5-73.5$ & 1745 & 1640 & 329 \\
\hline \multirow{3}{*}{6} & $\mathrm{Ph}$ & $167-170 \quad(\mathrm{dec})$ & 1765,1740 & 1650 & 487 \\
\hline & $1-\mathrm{Np}$ & $153-157 \quad(\mathrm{dec})$ & 1755 & 1650 & 587 \\
\hline & $2-\mathrm{Np}$ & $158-162(\mathrm{dec})$ & 1760,1735 & 1650 & 587 \\
\hline \multirow{3}{*}{$\mathbf{8 a}$} & $\mathrm{Ph}$ & $135.5-136.5$ & 1790,1770 & & 365 \\
\hline & $1-\mathrm{Np}$ & $88.5-90.5$ & 1780,1765 & & 415 \\
\hline & $2-\mathrm{Np}$ & $165-166$ & 1795,1760 & & 415 \\
\hline \multirow{3}{*}{$\mathbf{8 b}$} & $\mathrm{Ph}$ & $89-91$ & 1775,1760 & & 365 \\
\hline & $1-\mathrm{Np}$ & $119.5-122$ & 1780,1770 & & 415 \\
\hline & $2-\mathrm{Np}$ & $129-130$ & 1770,1765 & & 415 \\
\hline
\end{tabular}

a See Table II.

Table V. ${ }^{1} \mathrm{H}$ NMR parameters of products derived from telomers

\begin{tabular}{|c|c|c|c|c|c|c|}
\hline \multirow{2}{*}{ Product } & \multirow{2}{*}{ Proton } & \multirow{2}{*}{ Symbol } & \multicolumn{4}{|c|}{ Chemical shift $\delta / \mathrm{ppm}$} \\
\hline & & & $\mathbf{M M A}^{\mathrm{a}}$ & PhMA $^{a}$ & $1-\mathrm{NMA}^{\mathrm{b}}$ & $2-\mathrm{NMA}^{\mathrm{b}}$ \\
\hline \multirow{2}{*}{4} & $-\mathrm{CH}_{3}$ & A & 2.21 & 2.30 & 2.43 & 2.36 \\
\hline & $-\mathrm{CH}=$ & $\mathrm{T}$ & 7.26 & 7.54 & $-{ }^{d}$ & $-{ }^{d}$ \\
\hline \multirow{2}{*}{$6^{\mathrm{c}}$} & $-\mathrm{CH}_{3}$ & A & & 2.65 & 2.76 & 2.71 \\
\hline & $-\mathrm{CH}=$ & $\mathbf{U}$ & & 6.25 & 6.41 & 6.31 \\
\hline \multirow{4}{*}{$\mathbf{8 a}$} & $-\mathrm{CH}_{3}$ & A & 1.67 & 1.84 & 2.05 & 1.90 \\
\hline & $-\mathrm{CH}_{3}$ & B & 1.32 & 1.43 & 1.53 & 1.49 \\
\hline & $-\mathrm{CH}_{2}-$ & $\mathrm{K}, \mathrm{L}$ & 2.75 & 2.87 & 3.10 & 2.99 \\
\hline & $-\mathrm{CH}_{2}-$ & $\mathrm{M}, \mathrm{N}$ & $\begin{array}{c}3.383 .07 \\
(16.2)^{\mathrm{e}}\end{array}$ & $\begin{array}{c}3.413 .09 \\
(15.6)\end{array}$ & $\begin{array}{c}3.543 .18 \\
(14.4)\end{array}$ & $\begin{array}{c}3.503 .16 \\
(15.0)\end{array}$ \\
\hline \multirow{6}{*}{$\mathbf{8 b}$} & $-\mathrm{CH}_{3}$ & A & 1.66 & 1.82 & 2.00 & 1.93 \\
\hline & $-\mathrm{CH}_{3}$ & B & 1.53 & 1.58 & 1.63 & 1.62 \\
\hline & $-\mathrm{CH}_{2}-$ & $\mathrm{K}, \mathrm{L}$ & 3.242 .08 & 3.492 .17 & 3.792 .36 & 3.712 .32 \\
\hline & & & $(14.4)$ & $(14.4)$ & $(14.4)$ & $(15.0)$ \\
\hline & $-\mathrm{CH}_{2}-$ & $\mathbf{M}, \mathbf{N}$ & 3.18 & 3.24 & 3.513 .21 & 3.503 .20 \\
\hline & & & & & $(15.0)$ & $(15.6)$ \\
\hline
\end{tabular}

a Measured in carbon tetrachloride.

b Measured in chloroform- $d_{1}$.

c $6(\mathrm{R}=\mathrm{Ph})$ was measured in chloroform- $d_{1}$.

d Overlapped at aromatic proton signals.

e ( ), coupling const. $J$ in $\mathrm{Hz}$. 
Table VI. Elimination of 1-mers with TEA ${ }^{\mathrm{a}}$

\begin{tabular}{ccccc}
\hline & \multicolumn{2}{c}{ Yield of products $/ \%$} & & Recovd. \\
\cline { 2 - 3 } & 4 & 6 & & $\%$ \\
\hline $\mathrm{Me}$ & 78 & - & \\
$\mathrm{Ph}$ & 45 & 9 & & - \\
$1-\mathrm{Np}$ & 32 & 10 & & - \\
$2-\mathrm{Np}$ & 39 & 10 & & - \\
\hline
\end{tabular}

a Reaction time, $20 \mathrm{~h}$.

b See Table II.

Table VII. Elimination of st-dimers with TEA ${ }^{\mathrm{a}}$

\begin{tabular}{|c|c|c|c|c|c|c|c|}
\hline \multirow{2}{*}{$\mathbf{R}^{\mathbf{b}}$} & \multicolumn{6}{|c|}{ Yield of products $/ \%$} & \multirow{2}{*}{$\frac{\text { Recovd }}{\%}$} \\
\hline & 5 & $7 \mathbf{a}$ & $7 \mathbf{b}$ & $\mathbf{8 a}$ & $\mathbf{8 b}$ & monomer & \\
\hline $\mathrm{Me}$ & - & 17 & - & 6 & 7 & - & 65 \\
\hline $\mathrm{Ph}$ & 23 & 25 & - & - & - & 13 & - \\
\hline $1-\mathrm{Np}$ & 8 & 22 & 6 & - & - & 13 & - \\
\hline $2-\mathrm{Np}$ & 18 & 16 & - & - & - & 9 & - \\
\hline
\end{tabular}

a Reaction time, $30 \mathrm{~h}$.

b See Table II.

normal unsaturated compound $\mathbf{4}$, whereas the aromatic 2a was subject to scission of the principal chain by the action of TEA, and afforded the monomer and 5 besides the unsaturated compounds $\mathbf{7 a}$ and $\mathbf{7 b}$. Furthermore, the occurrence of the corresponding phenols was appreciably observed in the reaction of the aromatic 2a with TEA.

Catalytic Reaction by Silica Gel. The lactonization of dimeric telomers was induced by the catalytic action of silica gel. As shown in Table VIII, this reaction selectively proceeded by the following routes: $\mathbf{2 a} \rightarrow \mathbf{8 a}$ and $\mathbf{2 b} \rightarrow \mathbf{8 b}$, and the conversion yield of $\mathbf{2 b}$ was greater than that of $\mathbf{2 a}$. However, the lactonization of the aromatic telomers was considerably inferior to that of the aliphatic telomers such as MMA ones in lactone yields. The lactonization of the aliphatic telomers with silica gel is considered to take place through a cationic $S_{N}$ i mechanism as discussed in the preceding paper. ${ }^{8}$ If the same mechanism is applicable to the lactonization of the
Table VIII. Catalytic reaction of dimers with silica gel

\begin{tabular}{|c|c|c|c|}
\hline \multirow{2}{*}{ Dimer } & \multirow{2}{*}{$\mathbf{R}^{\mathbf{a}}$} & \multicolumn{2}{|c|}{ Lactone yield $/ \%$} \\
\hline & & $\mathbf{8 a}$ & $\mathbf{8 b}$ \\
\hline \multirow{4}{*}{$\mathbf{2 a}$} & $\mathrm{Me}$ & 86 & - \\
\hline & $\mathrm{Ph}$ & 21 & - \\
\hline & $1-\mathrm{Np}$ & 48 & - \\
\hline & $2-\mathrm{Np}$ & 23 & - \\
\hline \multirow{4}{*}{$\mathbf{2 b}$} & $\mathrm{Me}$ & - & $100^{b}$ \\
\hline & $\mathrm{Ph}$ & - & 69 \\
\hline & $1-\mathrm{Np}$ & - & 75 \\
\hline & $2-\mathrm{Np}$ & - & 76 \\
\hline
\end{tabular}

aromatic telomers, the aryl bromide will be obtained as a by-product. However, the lactonization of the aromatic telomers gave the corresponding phenol as a by-product. Consequently, the lactonization of the aromatic telomers with silica gel is considered to take place through the nucleophilic addition of the hydroxyl anion against the ester group, followed by the liberation of the aryloxy anion.

Pyrolysis. Table IX shows the results of the pyrolysis of $\mathbf{2 a}$ and $\mathbf{2} \mathbf{b}$ in the absence of solvent. Heating of such aliphatic telomers as 2a $(\mathrm{R}=\mathrm{Me})$ and $2 \mathrm{~b}(\mathrm{R}=\mathrm{Me})$ at $200^{\circ} \mathrm{C}$ for $2 \mathrm{~h}$ exclusively gave $\mathbf{8 a}$ and $\mathbf{8 b}$, respectively, by the same route as the catalytic lactonization with silica gel. Under similar heating conditions, both $2 \mathrm{a}(\mathrm{R}=\mathrm{Ph})$ and $2 \mathrm{~b}(\mathrm{R}=\mathrm{Ph})$ gave 7a $(\mathrm{R}=\mathrm{Ph})$ preferentially, whereas $2 \mathrm{a}(\mathrm{R}=1$ $\mathrm{Np)}$ was considerably subject to pyrolysis. Therefore, the pyrolysis of $\mathbf{2 a}(\mathrm{R}=1-\mathrm{Np})$ was followed with passage of time at $150^{\circ} \mathrm{C}$. Upon continuous heating for $2 \mathrm{~h}$, the internally unsaturated compound $7 \mathbf{b}(\mathrm{R}=1-\mathrm{Np})$ was obtained along with $7 \mathrm{a}(\mathrm{R}=1-\mathrm{Np})$ and $8 \mathrm{a}(\mathrm{R}=1$ $\mathrm{Np}$ ). Furthermore, heating longer than $4 \mathrm{~h}$ resulted in the following diastereoisomerization: $2 \mathbf{a}(R=1-N p) \rightarrow \mathbf{2 b}(R=1-N p)$. Similar pyrolysis behavior was observed on heating of $2 \mathbf{a}(\mathrm{R}=2-\mathrm{Np})$ and $2 \mathrm{~b}(\mathrm{R}=1-\mathrm{Np}, 2-\mathrm{Np})$ at 
T. Kimura, I. NaKanishi, and M. Hamashima

Table IX. Pyrolysis of dimers

\begin{tabular}{|c|c|c|c|c|c|c|c|c|c|c|}
\hline \multirow{2}{*}{ Dimer } & \multirow{2}{*}{$\mathbf{R}^{\mathbf{a}}$} & \multirow{2}{*}{$\frac{\text { Temp }}{{ }^{\circ} \mathrm{C}}$} & \multirow{2}{*}{$\frac{\text { Time }}{\mathrm{h}}$} & \multicolumn{6}{|c|}{ Yield of products/ $\%$} & \multirow{2}{*}{$\frac{\text { Recovd }}{\%}$} \\
\hline & & & & $7 a$ & $7 b$ & $8 \mathbf{a}$ & $\mathbf{8 b}$ & $2 a$ & $\mathbf{2 b}$ & \\
\hline \multirow{7}{*}{$2 a$} & $\mathrm{Me}$ & 200 & 2 & - & - & 100 & - & & - & - \\
\hline & $\mathrm{Ph}$ & 200 & 2 & 55 & - & 17 & - & & - & 28 \\
\hline & & 150 & 4 & 9 & - & 5 & - & & - & 86 \\
\hline & $1-\mathrm{Np}$ & 150 & 2 & 6 & 3 & 5 & - & & - & 85 \\
\hline & & & 4 & 13 & 6 & 9 & - & & 12 & 60 \\
\hline & & & 12 & 25 & 8 & 8 & - & & 11 & 47 \\
\hline & $2-\mathrm{Np}$ & 150 & 4 & 14 & 6 & 9 & - & & 9 & 62 \\
\hline \multirow{4}{*}{$\mathbf{2 b}$} & $\mathrm{Me}$ & 200 & 2 & - & - & - & 100 & - & & - \\
\hline & $\mathrm{Ph}$ & 200 & 2 & 48 & - & - & - & - & & 52 \\
\hline & $1-\mathrm{Np}$ & 150 & 4 & 26 & 22 & 7 & - & 29 & & 16 \\
\hline & $2-\mathrm{Np}$ & 150 & 4 & 26 & 8 & - & 10 & 14 & & 42 \\
\hline
\end{tabular}

a See Table II.

$$
\begin{aligned}
& \text { 2a or } \mathbf{2 b} \stackrel{-\mathrm{HBr}}{\longrightarrow} 7 \mathbf{b} \stackrel{\text { cleavage }}{\rightleftharpoons} \mathrm{Cl}_{3} \mathrm{C}-\mathrm{CH}_{2}-\left.\right|_{\mathrm{COOR}} ^{\mathrm{C}^{\mathrm{CH}}}+\cdot \mathrm{CH}={\underset{\mathrm{COOR}}{\mathrm{C}}}_{\mathrm{C}}^{\mathrm{CH}_{3}} \\
& \text { ( I ) } \\
& 2 \mathbf{a} \text { and } \mathbf{2 b} \leftrightharpoons \stackrel{\cdot \mathrm{Br}}{=} \text { two dimeric radicals } \stackrel{(\mathrm{I})}{=} \text { monomer }
\end{aligned}
$$

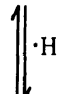

Scheme 1. Route of diastereoisomerization of dimeric telomers in pyrolysis.

$150^{\circ} \mathrm{C}$ for $4 \mathrm{~h}$, and the diastereoisomerization of $\mathbf{2 a} \rightleftarrows \mathbf{2 b}$ was found to take place in the pyrolysis of only NMA dimeric telomers.

\section{Mechanistic Consideration of Diastereoiso- merization in Pyrolysis}

Judging from the results in Table IX, the diastereoisomerization of dimeric telomers during pyrolysis is expected to proceed by one of the following routes. One route is an opposite addition of once released hydrogen bromide to $\mathbf{7 b}$, and the other one is a series of reactions accompanied by the depolymerization of $\mathbf{7 b}$ as shown in Scheme 1. If the diastereoisomerization proceeds by the former route, the same reaction will probably take place by way of 7a. However, such a diastereoisomerization was entirely unobserved in the pyrolysis of $2 \mathbf{a}(\mathrm{R}=\mathrm{Ph})$ and $2 \mathbf{b}(\mathrm{R}=\mathrm{Ph})$ which preferentially produced $7 \mathbf{a}(\mathrm{R}=\mathrm{Ph})$. Furthermore, the bubbling of hydrogen bromide gas into a mixture of $7 \mathbf{a}(\mathrm{R}=1-\mathrm{Np})$ and $7 \mathbf{b}(\mathrm{R}=1$ $\mathrm{Np})$ was attempted under several conditions, but the formation of $\mathbf{2 a}(\mathrm{R}=1-\mathrm{Np})$ and $\mathbf{2 b}$ $(R=1-N p)$ was not observed. On the other hand, $7 \mathbf{b}$ is liable to cause the depolymerization in comparison with $7 \mathbf{a}$ on the basis of the positional difference of the double bond. Furthermore, the fragment ion peak corresponding to NMA monomer was strongly detected in the mass spectra of $2 a(R=1-N p$, $2-\mathrm{Np})$ and $2 \mathbf{b}(\mathrm{R}=1-\mathrm{Np}, 2-\mathrm{Np})$. Consequently, it is considered that the latter route is applicable to the diastereoisomerization of dimeric telomers in the pyrolysis. 
Acknowledgments. The authors are grateful to Mr. Y. Ohsawa and Mr. Y. Ohtomo for their help in this study.

\section{REFERENCES}

1. C. A. Barson, R. R. Mather, and J. C. Robb, Trans. Faraday Soc., 66, 2585 (1970).

2. D. A. J. Harker, R. A. M. Thomson, and I. R. Walters, Trans. Faraday Soc., 67, 3057 (1971).

3. C. A. Barson, A. R. Luxton, and J. C. Robb, J. Chem. Soc., Faraday Trans. 1, 68, 1666 (1972).

4. C. A. Barson, R. A. Batten, and J. C. Robb, Eur.
Polym. J., 10, 97 (1974).

5. C. A. Barson and R. Ensor, Eur. Polym. J., 13, 53 (1977)

6. M. S. Kharasch, O. Reinmuth, and W. H. Urry, J. Am. Chem. Soc., 69, 1105 (1947).

7. T. Kimura, T. Kodaira, and M. Hamashima, Polym. J., 15, 293 (1983).

8. T. Kimura and M. Hamashima, Polym. J., 18, 21 (1986).

9. S. Patai, M. Bentov, and M. E. Reichmann, J. Am. Chem. Soc., 74, 845 (1952).

10. J. Nishino, H. Nakahata, and Y. Sakaguchi, Polym. J., 2, 555 (1971). 